\title{
NACIÓN, FÚTBOL E IMAGEN PUBLICITARIA: LOS SIGNIFICADOS DE LA COPA AMÉRICA DEL 2001 EN COLOMBIA ${ }^{1}$
}

\author{
NATION, SOCCER AND ADVERTISEMENT IMAGE: MEANINGS \\ OF AMERICA CUP 2001 IN COLOMBIA
}

\author{
Marlon Steve Celis Hernández*
}

RESUMEN

En este artículo se aborda la construcción de la idea de nación a partir de la imagen publicitaria en el contexto de la Copa América del 2001. Este certamen deportivo realizado en Colombia en paralelo con un proceso de paz fue denominado como la "Copa de la Paz". Se entiende así como un signo expresado en la imagen por medio del mensaje lingüístico, una imagen denotada y otra connotada. La metodología empleada fue revisión documental desde la Sociología y Semiología.

PALABRAS CLAVE: COLOMBIA * NACIÓN * FÚTBOL * IMÁGENES * PAZ * PUBLICIDAD

ABSTRACT

This article addresses the construction of the idea of nation from the advertising image in the context of the America Cup of 2001. This competition was made in Colombia in parallel with a peace process denominated the Peace Cup, thus allowing, in a sense as a sign expressed in the image through the linguistic message, a denoted image and a connoted image. The methodology was documentary review from Sociology and Semiology.

KEYWORDS: COLOMBIA * NATION * FOOTBALL * ILLUSTRATION * PEACE * ADVERTISING

$1 \quad$ Este artículo es producto del trabajo de grado "Nación e imagen: sobre los significados en el Centenario de la Independencia de 1910 y la Copa América del 2001" sustentado en el año 2015.

* $\quad$ Facultad de Sociología, Universidad Santo Tomás, Bogotá, Colombia.

mscelis1229@gmail.com 


\section{INTRODUCCIÓN}

El propósito del presente artículo es desarrollar una aproximación interpretativa de la idea de nación a partir de la imagen publicitaria referente al triunfo de la Copa América del 2001 por parte de la Selección Colombiana de Fútbol.

Este certamen deportivo que se desarrolló durante un proceso de paz con las Fuerzas Armadas Revolucionarias de Colombia-Ejército del pueblo (FarC-EP) es tomado como ejemplo de un signo constituido por un significado y significante. Es decir, la conceptualización otorgada a este evento deportivo denominado como la "Copa de la Paz" permite ser entendido desde la imagen como un elemento de expresión para su circulación nacional por medios de comunicación escrita, a partir de un mensaje lingüístico, una imagen denotada y connotada.

En primer lugar, son desarrollados algunos aportes $y$ estudios latinoamericanos sobre la temática alrededor del fútbol para dar paso a los postulados de Barthes (2009) en la caracterización del signo y de las imágenes. Así mismo, se desarrolla una contextualización del Proceso de paz y el certamen deportivo mencionado a partir de Medina (2009), Jaramillo (2007) y Hernando (1992) sobre el mensaje publicitario.

Asimismo, se consideran los postulados de Weber (1997) junto con Anderson (2011) sobre el concepto de la comunidad política y la nación. Por otro lado, como referente de interpretación del fútbol son abordados los de Elias y Dunning (1995), Oliven y Damo (2006), Dávila y Londoño (2002) y Villena (2003).

En segundo lugar, se plantea una hipótesis en la interpretación de la imagen y su relación con la idea de nación a partir de un deporte como es el fútbol para el año 2001. Es decir, la imagen publicitaria posiciona un concepto de la idea de nación para su circulación y socialización a través de un mensaje denotado sobre el fútbol a uno connotado en torno a la paz.

Cabe aclarar que la metodología empleada es una revisión documental a partir de dos medios de comunicación escrita: El Tiempo y El Espectador. Caracterizados por su circulación distrital y nacional, se constituyen en elementos de comunicación de las imágenes publicitarias en referencia a la idea de nación. Además, once imágenes son tomadas como muestra del total publicadas en estos medios de comunicación entre los días previos, durante y después (del 10 al 30 de julio de 2001) del triunfo de la Copa América. Finalmente, se da paso a una interpretación conjunta de lo esbozado y posibles escenarios de interpretación a partir de lo planteado.

\section{LA SELECCIÓN NACIONAL DE FÚTBOL Y NARRATIVAS DE NACIÓN}

Algunos antecedentes a nivel latinoamericano sobre fútbol y nación, relevantes a destacar son los de Villena (2009) y Alabarces (2006). Ambas perspectivas se interesan por analizar la construcción de discursos e imágenes nacionales que circularon en medios de comunicación dentro de certámenes deportivos internacionales, en los cuales participaron los seleccionados nacionales, siendo en el caso particular, Costa Rica y Argentina.

Para empezar, Villena parte por articular la publicidad con imaginarios nacionalistas que son sometidos a una producción simbólica de constante resignificación. Toma como ejemplo la publicidad que fue difundida en televisión dentro las eliminatorias a la Copa Mundial del 2002 por la Selección Nacional de Futbol mayor masculina de Costa Rica. Sin embargo, antes de desarrollar su análisis presenta una serie de postulados teóricos que orientan su interpretación. Por un lado, el discurso publicitario, busca "...persuadir a una audiencia determinada para que adquiera en el mercado un producto específico, cualquiera que éste sea, buscando establecer la lealtad del consumidor a la marca" (Villena, 2009, p. 2).

Además, presenta un acto perlocutivo, quien de manera utilitaria toma un imaginario social, el cual reproduce y resignifica para una audiencia potencial y multitudinaria. Repercutiendo así en la construcción de un ideal homogéneo de ser y de actitudes humanas. Producto de este tipo de relación, señala la capitalización de un valor simbólico en el subconsciente nacional, que al estar asociado con un producto comercial esta velado de prestigio $y$ posicionamiento. Por otro lado, este tipo de 
imágenes comerciales acude y reafirma una ideología propia del mercado en la medida que "Nos ofrece la felicidad mediante la adquisición y no mediante la participación" (Villena, 2009, p. 3).

En el caso de la selección de Costa Rica, en el periodo de las eliminatorias mundialistas, contaba con diez patrocinadores, quienes por medio de giros económicos a la Federación Deportiva hicieron uso de la imagen de la selección mediante la adquisición de derechos, producto de su patrocinio para la producción de publicidad. De igual manera, este tipo de campañas privilegiaron la relación entre el fútbol, el imaginario de nación y un producto para su consumo. Como fue señalado, Coca Cola es el primer ejemplo del autor, quien parte por caracterizar este producto como una bebida que ha tenido una expansión en los mercados y en la homogenización de los gustos, permitiendo así, en enmarcarlos dentro de una dinámica de globalización.

Una forma de entender esta relación es por medio de spots publicitarios transmitidos en televisión en que su eje central:

...busca ser cumplido explotando una larga tradición costarricense que ha convertido al fútbol en "juego patriótico", utilizando la imagen positiva que ha obtenido el fútbol de selecciones entre la ciudadanía-afición gracias a sus éxitos deportivos durante las eliminatorias (Villena, 2009, p.7).

Este tipo de participación visual busca el posicionamiento del consumo de una marca por medio de su contenido sonoro. Resaltando una nación por medio de los "ticos" y de iconos de centrales: la patria con la bandera, el fútbol con el balón y la bebida Coca Cola con el logotipo. Así que, al imaginar la nación “...difunde entre la afición el sentimiento de que sus celebraciones particulares son parte de una celebración mayor, simultánea $y$ de alcance nacional, en la que están involucrados todos los ticos y ticas" (Villena, 2009, p. 10).

Este tipo de publicidad que difundió una idea global de nación y celebración con el fútbol, de manera paralela le acompaña una segunda publicidad realizada por Cristal. Esta marca de agua de la Cervecería de Costa Rica (ccR) y siendo una bebida no alcohólica embotellada marcó un mensaje de nacionalismo futbolístico en relación a un imaginario emotivo con la bandera y la camiseta. En otras palabras, “...se trata de un proceso reflexivo-expresivo sobre la identidad costarricense bajo la forma de endoidentidad, puesto que es realizado por "ticos" y dirigida a "ticos" " (Villena, 2009, p. 12).

Dentro del análisis expuesto, retoma de igual manera, el registro sonoro y caracteriza una celebración nacionalista en que predominó un reconocimiento de un "nosotros esencial" $y$ de orgullo en tres etapas: los preparativos, la prueba $y$ la celebración de la victoria. También, la movilización de la nación por medio de sueños colectivos, los valores de la tradición nacional, el contenido y alegoría a la nación en ascenso $y$ crecimiento. Una forma de entenderlo es con la idea de una nación triunfadora y su relación con la imagen publicitaria. Esta, evocó frente al televisor, escenarios rurales como de encuentro familiar. Atribuyó valores simbólicos de devoción, sacrificio, patria, la bandera $y$ virtudes. Lo anterior, con el propósito de identificar:

así, por más solemnidad que pretende transmitir el anuncio, la necesidad publicitaria de "anclar" la marca en la conciencia del consumidor conduce, en último término, a una devaluación de los símbolos nacionales, así como del mismo fútbol. Sin duda, este es un rasgo central del ideologema de la publicidad: banaliza los contenidos de la tradición y sacraliza los productos (Villena, 2009, p. 15).

Desde la perspectiva del autor, el fútbol se encuentra en un proceso de comercialización e hipermediatización permeado por el financiamiento privado de equipos deportivos. Más aun, dentro de un marco de globalización, en que los imaginarios con fines utilitarios transforman el discurso nacionalista a uno banalizado en función de la sacralización de un producto dentro del mercado.

La idea de comunidad transita hacia el anonimato por los consumidores, carente de unificación y sustentando un nacionalismo "tico" 
por medio de la selección para su celebración patriótica. A finde señalar una paradoja: “...el potencial movilizador del nacionalismo se orienta hacia fines globalizadores, desplazándose de las pretensiones humanísticas de crear ciudadanía hacia los objetivos neoliberales de conquistar consumidores" (Villena, 2009, p. 19-20).

Los anteriores postulados se articulan con Alabarces (2006) en la medida que aborda las narrativas nacionales de Argentina con el fútbol. Este autor y compilador de textos como Futbologías (2003) y Peligro de Gol (2000), propone desde la invención de significados y discursos massmediáticos, el posicionamiento de una "cultura futbolística argentina" marcada por la segmentación y la exclusión, así como por la unificación entorno a la pasión en el fútbol. Al tomar el Campeonato Mundial de Fútbol y proponer un recorrido histórico nacional frente a este deporte (que pasa con la fundación de un estilo criollo en los años 20, el peronismo, el papel protagónico y heroico de Maradona y la contemporaneidad) afirma un juicio central para la comprensión de esta realidad social:

en momentos de politización fuerte de los debates sobre lo nacional, la centralidad de las narrativas futbolísticas decrece, hasta transformarse en pura mercancía mediática (o presunto argumento de ventas). Pero que en momentos de crisis de los relatos modernos de identidad, la importancia de las narrativas futbolísticas crece de manera importante, excediendo incluso el mundo masculino donde originalmente se despliegan (Alabarces, 2006, p. 4).

Conforme con lo anterior, una manera de entender este escenario es la ruptura de procesos de integración social. El protagonismo del mercado sobre el estado repercute en posicionar un rol de consumidores excluidos $y$ de la autonomía con que cuentan enunciadores (periodistas, directores de cine, narradores, entre otros) construyendo narrativas dentro de su contexto, repercutiendo en una construcción de nación e identidad. Esta última, “...se transforma en este repliegue en un consumo socio-estético, en un relato sin estructura, en una mera posición de sujeto donde la única determinación es la posición sintáctica" (Alabarces, 2006, p. 7).

Además, con la transmisión de encuentros deportivos por televisión, la nación futbolística es repuesta por la industria cultural. A su vez, dentro de la acumulación económica, "el gran narrador" de narrativas nacionales atribuido al Estado, es relevado por los medios de comunicación. Dentro de este escenario, los medios responden a una identidad tribal como nacional. Es decir, la "Vieja Nación" con nuevas narrativas $y$ de consumo. En palabras de Alabarces (2009), narra la nación como un consumo y “...el fútbol no es una maquina cultural de nacionalidad posmoderna; esa máquina es la televisión. Y el fútbol es solo uno de sus géneros, aunque sea el más exitoso" (p.13).

Finalmente, en esta práctica deportiva dentro del contexto argentino $y$ de dictadura entre los años 1976 a 1983, el fútbol articularía un nuevo relato nacional. Caracterizado por la construcción de héroes deportivos y el retiro de Maradona que soportaron nuevas narrativas. Además, en el año 2001, en las manifestaciones ciudadanas, las banderas y las camisetas de la selección son protagonistas dentro de un escenario político.

Una vez dada esta caracterización entre fútbol y patria, el autor propone que los medios generan el deseo de comunidad en que la publicidad de marcas nacionales $y$ transnacionales “...dedicaron sus afanes a la banalización del patriotismo, a proponer el recurrente relato nacionalista que dominó nuevamente a la mayoría del periodismo deportivo" (Alabarces, 2006, p. 15), repercutiendo así en la denominación de hinchas, (tele)espectadores, entre otros. En un plano real, es producto de las condiciones sociales, económicas, políticas e históricas.

\section{“GOLES EN PAZ” EN LA CIUDAD DE BOGOTÁ}

Un ejemplo a destacar dentro de la relación de fútbol, paz y violencia en Colombia es el programa "Goles en paz" de la ciudad de Bogotá. Si bien, este se caracterizó por realizarse en la capital, es relevante dentro de su contexto de producción. Para empezar, este programa distrital tiene sus antecedentes finalizando 
"...la década de los noventa, bajo el nombre de "jugando limpio todos ganamos" nombre que se dio a las acciones institucionales emprendidas para contrarrestar los hechos de violencia que se venían presentando entre hinchas, principalmente de los equipos capitalinos..." (Gómez, 2014, p. 83).

El interés de este programa fue crear estrategias de convivencia en el estadio, entre las barras de los equipos nacionales (se destacan Millonarios, Santa Fe, Nacional y América) que congregaban un gran número de seguidores en la ciudad. Hacia el año 2000, el programa nace por parte de la Alcaldía Mayor de Bogotá dentro de una propuesta de "Cultura Ciudadana" por la vida, el desarme y el fútbol.

En este último aspecto, es importante destacar la labor, dirección y acompañamiento del sacerdote Alirio López Aguilera desde el 2001, quien se interesó por las problemáticas como manifestaciones de violencia que acontecían en los estadios. Ejemplo de ello es el reportaje y la entrevista concedida a José David López en el año 2015 de la Revista Digital El Enganche de España y publicada en su página oficial señalando que:

En la alocada Bogotá y en la pasional Colombia, quien más luchó por separar fútbol de extorsión, muertes de estadios y pasión de violentos, fue, es y será el Padre Alirio. Él, llevó su experiencia a la pelota para separarla de quienes la usan como vehículo de sus problemas. Él, como todos, solo quiere disfrutar de "Goles en Paz" (López, 2015).

Siguiendo con la caracterización, este programa se orientó en la intervención de escenarios conflictivos y de violencia mediante la vinculación de diferentes instituciones estatales $y$ de las barras de los equipos de fútbol nacional. Por ejemplo: el Instituto Distrital para la Recreación y Deporte, la Policía Nacional, Clubes Deportivos, entre otros; con el objetivo de reducir los niveles de violencia que acontecían para la época. Asimismo, en el caso particular, López enfatizó:

Se ha trabajado por un barrismo futbolero o barras populares con productividad $y$ oportunidades de vida. Es un proceso lentísimo pero con sentido de pertenencia de unos y de otros. Todo para salvar el fútbol ante tanta violencia, no solamente en Colombia. La meta es alcanzar a que cada estadio del mundo sea un territorio de paz y de vida sagrada (2015).

Además, frente a las manifestaciones de violencia, el programa fue socializado en diferentes espacios pedagógicos, sociales y deportivos proponiendo una idea de hermandad $y$ de responsabilidad entre los mismos, de tolerancia y respeto. Incentivó proyectos en formación de liderazgo, trabajo en empresas, torneos de fútbol de salón, pactos de convivencia, talleres de música, foros académicos, semilleros de "Goles en paz" con menores de edad y el trabajo de campo realizado en Chile y Argentina como países referentes en la construcción del programa para la ciudad.

Por otro lado, se presentaban jornadas de desarme, de acompañamiento a los jóvenes y de una estructura que soportó el programa. Como lo señala López en la entrevista al medio web $E l$ Enganche, fue orden y escucha desde un enfoque de disciplina. Es decir:

1) Acercamiento con los líderes de las diferentes barras.

2) Organizar reuniones y crear el comité de seguridad, integrado por gobierno, policía, alcaldía local, personería, líderes de las barras, representante de las barras organizadas, representantes de los equipos, logística, Cruz Roja, secretaría del deporte, de Salud, entre otras.

3) Se creó el primer protocolo de Goles en Paz, (manejo de barras,). Bajo tres aspectos: auto-control, hospitalidad y creatividad. Funcionó hasta el 2009, hasta que llegó una nueva administración muy "creativa" y acabó con todo el proceso y logros que se había alcanzado (López, 2015).

Frente a este último, el programa tuvo cambios de acuerdo a los lineamientos de la administración distrital a cargo de la Secretaría 
de Gobierno orientada por un enfoque de seguridad y convivencia. Asimismo, se constituyó la Ley 1270 de 2009 que creó la "Comisión Nacional para la Seguridad, Comodidad y Convivencia en el Fútbol a nivel nacional", vinculando: los ministerios de gobierno nacional, fiscalía, procuraduría, directivas de fútbol nacional, representantes de la Federación Colombiana de Fútbol, Defensor del Pueblo, empresas encargadas de espectáculos de fútbol, Comisión Arbitral, un delegado de las barras existentes en el país, entre otros. Se destaca en este aspecto el artículo nro. 1 de dicha ley:

Creación de la Comisión Nacional de Seguridad, Comodidad y Convivencia en el Fútbol. Créase la Comisión Nacional de Seguridad, Comodidad y Convivencia en el Fútbol, como organismo asesor del Gobierno Nacional en la implementación de políticas, planes y programas, así como en la ejecución de estrategias dirigidas a mantener la seguridad, comodidad $y$ convivencia en la organización y práctica de este espectáculo deportivo. La Comisión tendrá su sede en Bogotá, D. C., estará bajo la dirección del Ministerio del Interior y de Justicia, quien contará con la asesoría y asistencia técnica del Instituto Colombiano del Deporte - Coldeportes(Ley 1270, 2009).

Frente a este nuevo escenario de fútbol y de barras futboleras, Gómez (2014) plantea un cambio en la administración pública que repercutiría en continuidades y rupturas dentro del programa de "Goles en Paz". Se privilegió una configuración de seguridad:

...desde la perspectiva de exclusión de los antagonistas, dependiendo de quienes sean los locales o anfitriones, dejando por fuera a los rivales en tanto espectadores. Esto construye fronteras simbólicas que implican la construcción de territorios de exclusión (p. 85).

Finalmente, como lo señaló el Padre Alirio, en la entrevista concedida a la revista $E l$ Enganche, invita a mirar de manera integral la realidad del fútbol desde una perspectiva social como cultural, que involucre la psicología del “...jugador, del dirigente, del comentarista deportivo, del técnico y del ambiente en el cual se mueven unos $y$ otros. Porque ante todo $y$ para todos, el fútbol es la religión del Siglo xxı, la única que no tiene ateos" (López, 2015).

Cabe señalar, que el sacerdote deja la dirección del programa "Goles en paz" en el año 2008. También, fue retomada esta propuesta por organizaciones sociales en la ciudad como a nivel nacional, para la formulación y desarrollo de proyectos sociales por medio del fútbol.

Conforme a lo mencionado, esta experiencia en Bogotá y los antecedentes, son relevantes para el presente artículo. Esto con el propósito de identificar líneas interpretativas, tanto teóricas y prácticas, que contribuyen a comprender realidades sociales en torno al fútbol a nivel local, nacional e internacional. Siguiendo la perspectiva de los estudios latinoamericanos, se da paso al análisis de la imagen con la idea de nación publicada en medios de comunicación escrita, dentro de su contexto de producción; siendo en el caso particular, el Proceso de Paz que acontecía hacia el año 2001 en Colombia.

\section{DE LA COPA AMÉRICA A LA COPA DE LA PAZ}

Para empezar, las imágenes publicitarias referentes al triunfo de la Copa América del 2001 o la "Copa de la Paz" son entendidas, a continuación, como un signo (significado y significante) asociado con la idea de nación. Siguiendo los postulados de Roland Barthes (2009), el "signo" se caracteriza por estar “... compuesto por un significante $y$ un significado. El plano de los significantes constituye el plano de expresión, y el de los significados, el plano del contenido" (p. 53.) Es decir, el signo se caracteriza por estar conformado por un significado referente al concepto $y$ un significante quien expresa el concepto o la imagen acústica.

El "significante" se caracteriza por ser un "...mediador: la materia le es necesaria, $y$, por otra parte, en semiología, el significado puede ser también reemplazado por cierta materia; la de las palabras" (Barthes, 2009, p. 61). A partir de lo anterior, en el contexto de la Copa América del 2001, el significante hará referencia a las 
imágenes publicitarias publicadas en medios de comunicación escrita. Así mismo, al estar acompañadas de mensajes lingüísticos e imágenes denotadas y connotadas se constituyen en la expresión (significante) del concepto (significado). Por tanto, el "significado" es:

definido más que en el interior del proceso de significación, de una manera casi tautológica: es ese «algo» que el que emplea el signo entiende por él. Se llega de esta manera a una definición puramente funcional: el significado es uno de los dos relata del signo; la única diferencia que lo opone al significante es que éste es un mediador (Barthes, 2009, p. 56).

Como se ha mencionado, el significado se caracteriza por ser la conceptualización del signo y será entendido en las imágenes publicitarias del triunfo de la Copa América del 2001 a partir de su contenido y contexto como se expresa a continuación.

\section{IMAGEN PUBLICITARIA Y EJES DE INTERPRETACIÓN}

En primer lugar, la imagen se caracteriza por estar relacionada con la imitación o una representación analógica. En el caso particular de la imagen publicitaria, su significación es intencional en la medida que:

determinados atributos del producto forman a priori los significados del mensaje publicitario, $y$ estos significados deben ser trasmitidos con la mayor claridad posible; si la imagen contiene signos, tenemos la certeza de que esos signos están completos, formados de manera que favorecen su mejor lectura: la imagen publicitaria es franca 0 , por lo menos enfática (Barthes, 1986, p. 30).

Las imágenes publicitarias son entendidas como elementos que representan y comunican significados y significantes, donde su uso permite la comprensión, descripción e interpretación de acontecimientos pasados o presentes. Asimismo, estas imágenes permiten explicar su relación y conceptualización con la idea de nación.

Por otro lado, para desarrollar la interpretación de las imágenes publicitarias se retoma la perspectiva de semiológica a partir de la relación de tres ejes. El primero, hace referencia al mensaje lingüístico, el cual es entendido a partir de los textos y titulares que hacen parte de la imagen. En resumen, “...el mensaje lingüístico está presente en todas las imágenes: bien bajo forma de titular, texto explicativo, artículo de prensa, dialogo de película o globo de comic..." (Barthes, 1986, p. 35).

El siguiente eje es la imagen denotada, la cual se caracteriza por referenciar una imagen literal e información. En palabras de Barthes (1994) “... (la aparente literalidad de la imagen, del objeto, de la frase), cuya función es naturalizar la proposición de clase dándole la garantía de la naturaleza mas <<inocente>>: la del lenguaje (milenario, materno, escolar, etc.)" (p. 84). Finalmente, se encuentra el eje de la imagen connotada; caracterizada por su mensaje simbólico y cultural como también, por retomar del mensaje lingüístico y la imagen denotada. Su “...significado es ideológico (y en consecuencia $<<$ recto $>>$, $<<$ no invertido $>>$, o, para ser más claro, aunque tenga que hablar un lenguaje moral, cínico)” (p. 84).

\section{COLOMBIA, DIÁLOGO DE PAZ Y DEPORTE}

Durante el periodo presidencial de Andrés Pastrana (1998-2002) se desarrolló un proceso de paz con las Farc-EP en el territorio nacional, específicamente en San Vicente del Caguan junto con el despeje de cuatro municipios: La Uribe, Mesetas, La Macarena y Vista Hermosa.

Este proceso inició en enero de 1999 y posteriormente en el mes de mayo establecieron una agenda denominada como: Agenda Común. En esta última, se dialogaría una solución política negociada, derechos humanos, una política agraria integral, la explotación y conservación de recursos naturales, estructura económica y social, reformas a la justicia, política y estado, las relaciones internacionales, entre otros (Medina, 2009). 
Asimismo, este proceso de paz desarrollado en el país, se caracterizó por su suspensión y reactivación en diferentes momentos. Ejemplo de lo anterior, son los meses de junio $y$ julio, en los cuales el "...proceso se enreda a tal grado que se produce un aplazamiento indefinido de las negociaciones, pese a lo acordado por el alto Comisionado para la Paz $y$ los Negociadores de las FARC-EP, de retomar el 19 de julio 1999 las conversaciones" (Medina, 2009, p. 102).

Por otro lado, una vez retomada las reuniones y para final de año e inicio del 2000 , se estableció la metodología de negociación en la cual se abordarían a lo largo del año los doce temas de la Agenda Común, junto con la participación de otros países en el proceso, el desarrollo de audiencias públicas nacionales e internacionales y la conformación de comisiones que acompañarían la mesa del proceso de paz.

Sin embargo, para el mes "de noviembre de 2000 a febrero de 2001 los diálogos se interrumpen por la dinámica del conflicto armado y del mismo proceso de Paz, relacionados con los tiempos de la zona de distención y los reconocimientos institucionales formales al proceso" (Medina, 2009, p. 116). Acorde con lo anterior, una vez iniciado el año 2001, se llevaron a cabo el Acuerdo de los Pozos y la Resolución nro. 5, en la cual las partes dan continuidad al proceso de paz. Se retoma los diálogos y la conformación de una comisión de países latinoamericanos, europeos y organismos internacionales para acompañar posteriormente el intercambio humanitario.

Igualmente, en el transcurso de ese año se da a conocer el informe de la Comisión de Notables, momento simultáneo en el cual ponen “...a consideración de la Mesa de Diálogo y Negociación las recomendaciones, el proceso ya ha comenzado a transitar el camino de la ruptura, varios acontecimientos se van sumando para generar unas condiciones adversas al reinicio del proceso de diálogo" (Medina, 2009, p. 141). Lo anterior implica en dar por terminado dicho proceso de paz en el transcurso final del año 2001 y en el mes de febrero de 2002.
Además, dentro de este contexto de negociación, la Copa América de 2001 fue denominada como la "Copa de la Paz". Es decir, este certamen deportivo fue asignado a $\mathrm{Co}$ lombia en el año de 1997 por la Confederación Suramericana de Fútbol (csf). Sin embargo, en el transcurso del tiempo y hasta el 2001, se presentaron una serie de acontecimientos relevantes antes de su inicio. Ejemplo de esto último, fue la explosión de bombas en diferentes ciudades del país, el secuestro de dirigentes deportivos y políticos, la ausencia de la selección Argentina de fútbol en la copa, la suspensión del certamen, y su posterior ratificación para el mes de julio de 2001 con el respaldo de las federaciones deportivas de los países suramericanos junto con las instituciones nacionales. En resumen:

Esta confianza entregada a los colombianos por parte de la familia del fútbol suramericano hizo que el Gobierno, sus autoridades, medios de comunicación, instituciones públicas y privadas, $y$ en general toda la población, emprendieran una campaña para unir a Colombia alrededor de la "Copa de la Paz" (Jaramillo, 2007, p. 781).

Por esta razón, la Copa América o la "Copa de la Paz" permite ser un elemento de interpretación en relación a la conceptualización otorgada a este certamen deportivo dentro del proceso de paz. Las imágenes publicitarias que circularon en medios de comunicación escrita son elementos de análisis en referencia a la construcción de una idea común representada en sentimientos o valores sociales, una cohesión social, la consecución de la legitimidad de las instituciones, entre otros; relacionados con la idea de nación. Cabe señalar que dentro de este evento deportivo se difundió publicidad en medios de comunicación escrita, audiovisuales, televisión, radio, en productos de consumo masivo, entidades bancarias, instituciones públicas y privadas, empresas, entre otros. 
En el caso particular, se tomó una muestra de once imágenes públicas en el periódico El Tiempo y El Espectador. Estos medios son característicos en Colombia por su circulación nacional y alto tiraje. Además, sus orígenes se remontan desde la década de los 80 del siglo xix en el caso del El Espectador y en 1911 con la fundación de El Tiempo. El público receptor y sus lectores a destacar son los suscriptores, la comercialización en puntos de venta o con voceadores de prensa, página web y la difusión de imágenes a gran escala como en otros medios. Actualmente, se encuentran compilados y en archivo en la Biblioteca Nacional de Colombia y La Biblioteca Luis Ángel Arando.

Las ediciones que circularon a lo largo de la Copa América, contaron en ambos periódicos, con una sección exclusiva sobre el certamen. Con la actuación de la Selección Colombia publicaron imágenes alegóricas sobre la paz, las cuales tuvieron un incremento y mayor difusión en la final entre Colombia y México. Igualmente, esta muestra buscar dar a conocer los diferentes mensajes que circularon en estos medios de comunicación escrita con diferentes emisores, quieres serían los significantes bajo un mismo significado sobre la paz.

Para llevar a cabo la interpretación de las imágenes publicitarias se plantean cuatro ámbitos donde se describen y explican de manera particular (mensaje lingüístico e imagen denotada) para dar paso a una interpretación conjunta (imagen connotada) referente a cada sección. Dicha distribución es la siguiente: imagen, comunidad política e institución; imagen, fútbol e idea de nación; imagen y contexto nacional; imagen, idea de nación y su posicionamiento al exterior.

\section{IMAGEN, COMUNIDAD POLÍTICA E INSTITUCIÓN}

La primera imagen (Figura 1) de esta sección, fue publicada en la apertura del certamen deportivo y desde el inicio se enunció sobre la base de los siguientes mensajes lingüísticos:
“Estamos Esperando!” y en segundo lugar, afirma "Que con esta Copa América nazca entre nosotros el espíritu de fraternidad y paz que nos una. Bienvenidos a la Copa América, bienvenidos a la Copa de la Paz".

\section{FIGURA 1}

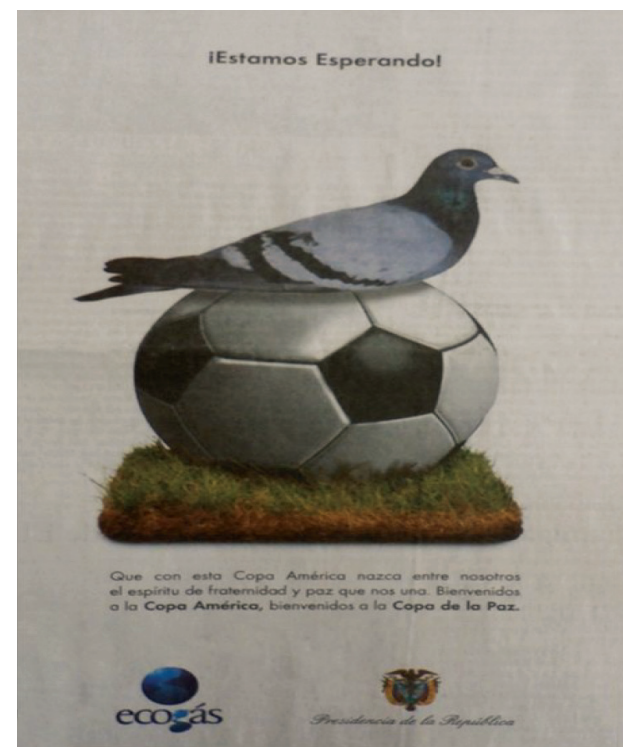

Fuente: El Espectador, 11 de julio de 2001, pág. 3a, sección: Judicial.

Dentro de la figura 1, su imagen denotada se caracteriza por ubicar una paloma en una posición conocida como incubación, empollando un balón de fútbol sobre un césped. Asimismo, es importante destacar dentro de esta imagen por estar acompañada de dos íconos: el de una empresa pública para la época distribuidora de servicios de gas, la Empresa Colombiana de Gas (Ecogás) y el escudo de Colombia referenciando consigo a la Presidencia de la República.

En la segunda imagen (Figura 2) referente al triunfo de la Copa América del 2001, su mensaje lingüístico se caracteriza en dos momentos: "Con la confianza nació una ilusión" y "Gracias por creer, por apoyarnos y por hacer parte de nuestra ilusión. Gracias a todos por hacer de esta Copa América, la Copa de la Paz". 
FIGURA 2

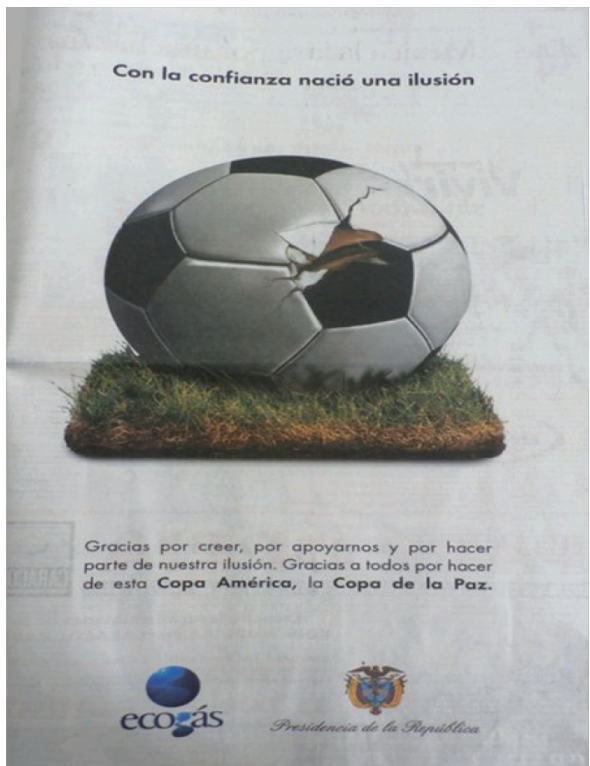

Fuente: El Espectador, 29 de julio de 2001, pág. 11c, sección: Copa América.

Además, la imagen denotada se caracteriza por retomar la anterior imagen, pero en esta ya no se encuentra la paloma sino un gran balón de fútbol que se ha quebrado para dar paso a un nacimiento, siendo en el caso particular, asomarse un pico de un ave asociado con un águila o cóndor. Igualmente, se encuentran los dos íconos mencionados en la primera imagen: el de Ecogás y el escudo de Colombia.

El mensaje lingüístico de la tercera imagen (Figura 3), se caracteriza por afirmar lo siguiente en tres momentos: "Colombia le cumplió a la Copa América, la Copa de la Paz", "Ahora... Hay que cumplirle a Colombia: No te olvides de la factura" y "No compres nada de contrabando". Cabe destacar, dentro de los anteriores textos, el uso de colores asociados a los de la bandera nacional como el verde de la Dirección de Impuestos y Aduanas Nacionales (Dian).

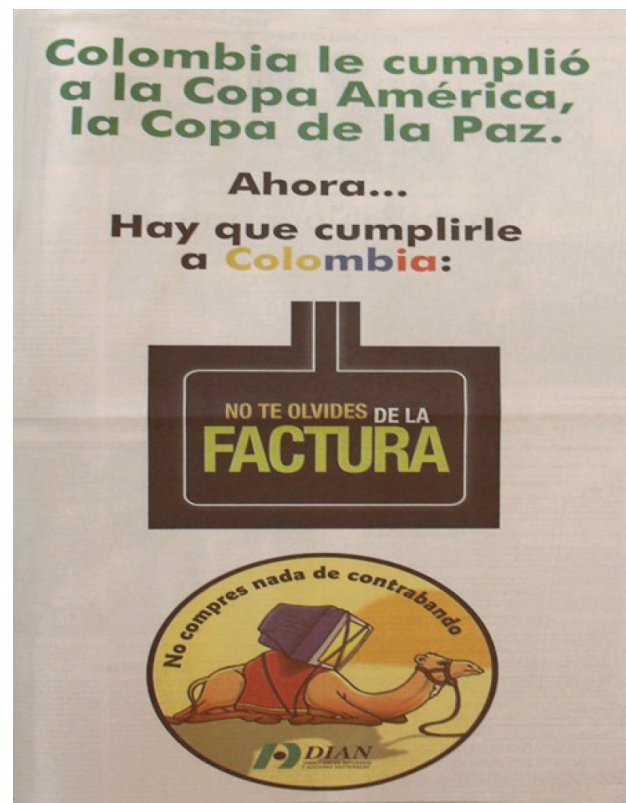

Fuente: El Espectador, 29 de julio de 2001, pág. 13c, sección: Copa América.

De igual manera, la imagen denotada, puede ser asociada con el camello que se encuentra representado, el cual se encuentra en el desierto llevando consigo amarrado un televisor $y$ en la parte inferior, se encuentra el ícono de DIAN de la época.

A partir de lo indicado, la imagen connotada de las tres imágenes mencionadas (figuras 1, 2 y 3 ) es relacionada con la construcción de un significado sobre la comunidad política y nación. Además, el posicionamiento de un mensaje desde el ámbito institucional acerca de la Copa América para su circulación nacional.

Al retomar los postulados de Weber (1997) acerca del pathos que se construye alrededor de la comunidad política, es asociado en el presente caso, con el significado expresado en las anteriores imágenes. 
Es importante indicar que la comunidad política es entendida como:

... aquella cuya acción consiste en que los partícipes se reservan la dominación ordenada de un "ámbito" (no necesariamente constante en absoluto $y$ delimitado con fijeza, pero sí delimitable de algún modo) y de la acción de los hombres situados en él de un modo permanente o sólo provisional, teniendo preparada para el caso la fuerza física, normalmente armada (Weber, 1997, p. 661).

Con lo anterior, se quiere hacer referencia en que la comunidad política al ser un referente conjunto con el concepto de nación, las imágenes son orientadas por el posicionamiento de una acción de respaldo al certamen deportivo $y$ la institucionalidad, infundiendo un sentimiento colectivo en la población receptora de la imagen dentro de un contexto de negociación de paz.

Una forma de ejemplificar lo mencionado es por medio del lenguaje; es decir, dentro en un medio de comunicación escrita de circulación nacional, la imagen connotada de tipo institucional referencia una idea de país desde al deporte, circulando en el territorio $y$ en el escenario público de la comunidad política. Además, el castellano, como idioma oficial de Colombia reconocido en la Constitución Política de 1991 frente a las lenguas $y$ dilectos de grupos étnicos dentro de sus territorios.

Asimismo, los sentimientos asociados con la moral que identifica la imagen connotada, se caracterizan en las imágenes por la evocación de un espíritu alrededor de la "Copa de la Paz". Lo anterior denota que la fraternidad, la creencia y la ilusión en el desarrollo de la Copa América dentro de los diálogos de paz se constituyeron en soporte junto con la imagen denotada en la significación de un ícono nacional como es el escudo y el fútbol dentro del contexto de 2001. De igual manera, la paz se constituyó o asoció con una idea de nación y país dentro de la solemnidad representada en un certamen deportivo y su respaldo en la transición del carácter recreativo a uno político de carácter nacional frente a lo que acontecía para la época.

Retomando los postulados de Weber (1997) sobre la comunidad política, plantea la violencia como un hecho primitivo. En sus palabras, como "resultado de una evolución lo es sólo el monopolio del poder legítimo mediante la asociación política territorial y su socialización racional hasta constituir una organización tipo instituto" (p. 664). Dicho de otra manera, al instituto (institución) se le reconocen las funciones básicas del Estado (función legislativa, protección de seguridad personal y orden público, justicia, ramas de administración y el régimen militar).

Cabe subrayar, que se estableció una relación entre las imágenes, las instituciones y el espectador. El triunfo de la Copa América fue caracterizado como la vinculación de las instituciones y el espectador de las imágenes, en que estas últimas se orientan en la consecución de una legitimidad o creencia de la comunidad política y el accionar de las instituciones estatales en torno a la paz.

Asimismo, las imágenes buscan implementar o socializar un mensaje a las personas vinculadas a un territorio, siendo en el caso particular Colombia. Esto refiere a la conceptualización de la legalidad como el respaldo a las instituciones, donde las imágenes y los textos condensan un mensaje institucional a uno nacional. Dicho concepto es asociado en la regulación de las acciones de las personas, siendo en el caso particular, un ámbito económico denotado a uno connotado en referencia a un espacio participativo dentro de la institucionalidad como deber y disyunción de la ilegalidad. 
Igualmente, dentro de este contexto de diálogos de paz, las imágenes son orientadas en vincular a la población en torno a un certamen deportivo conceptualizado $y$ expresado en el fútbol, como un elemento de cohesión social desde lo señalado en sus mensajes denotados y connotados. Finalmente, las imágenes que hacen parte de esta sección se caracterizan por la definición de un mensaje institucional, el cual se construye conforme al contexto nacional de la época y por ser naturalizado en las otras imágenes publicitarias.

Esto señala la relación de los mensajes lingüísticos y las imágenes denotadas de esta primera parte con las demás imágenes publicitarias acerca del accionar institucional y su respaldo por otros actores. En otras palabras, la paz al ser un mensaje presente en las imágenes de acuerdo al contexto de 2001 , busca sentimientos colectivos para su circulación en el escenario público por medio de un evento deportivo definido como la "Copa de la Paz".

Lo mencionado es representado en la imagen donde va nacer un ave. Siendo el cóndor un ícono nacional, que por su gran dimensión es comparada con el nacimiento de un sentimiento de fraternidad, paz e ilusión colectiva que soportan sentimientos humanos o pathos de la comunidad política como de la nación en Colombia. La construcción de esta idea para el año 2001, sustentada en un evento deportivo, se caracteriza por su relevancia dentro de la historia nacional y deportiva junto al proceso de paz de la época.

\section{IMAGEN, FÚTBOL E IDEA DE NACIÓN}

En la figura 4, su mensaje lingüístico expresa lo siguiente: "pinturas amarillo, azul y rojo: $\$ 5.000$ bandera gigante: $\$ 40.000$ camiseta de la selección: $\$ 50.000$ que Colombia sea el campeón: no tiene precio" y "MasterCard felicita a Colombia, el gran campeón de la Copa América, y todos sus hinchas que nunca dejaron de alentarlo".

\section{FIGURA 4}

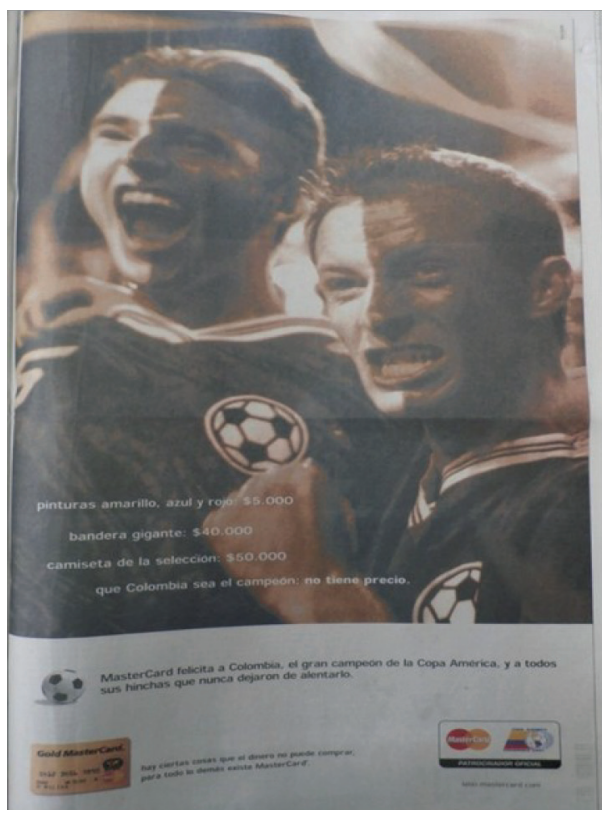

Fuente: El Tiempo, 30 de julio de 2001, pág. 4, sección: Copa América.

De igual manera, la imagen denotada se caracteriza por dos personas cuyas caras se encuentran pintadas acorde a la camiseta deportiva que visten. El lugar donde se encuentran puede ser asociado al estadio. Sus expresiones faciales o corporales son relacionadas con el disfrute $y$ triunfo del encuentro deportivo siendo en el caso particular, fútbol. Además, esta imagen es acompañada de otros íconos como son: un balón, la tarjeta Gold de MasterCard y su leyenda como patrocinador oficial del evento.

Cabe destacar una imagen (figura 5) en esta sección con los siguientes mensajes lingüísticos: "Colombia mostró su corazón y una sola camiseta a toda América", "IFelicitaciones Selección Colombia!", "Con amor y paz hicimos un sueño realidad". Se referencia la marca patrocinadora de ropa deportiva de la época para la Selección Colombia, es decir, Reebok. 


\section{FIGURA 5}

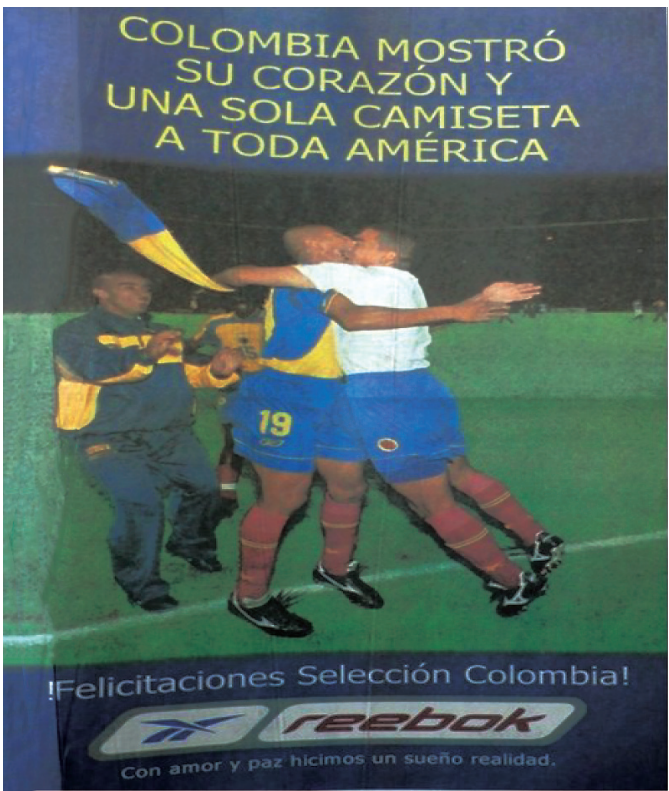

Fuente: El Tiempo, 30 de julio de 2001, pág. 7, sección: Copa América.

Por otro lado, la imagen denotada está representada con una fotografía en el momento del triunfo de la Copa América de 2001, donde aparecen dos jugadores de la selección colombiana de fútbol, Víctor Aristizabal y Freddy "El Totono" Grisales - referentes importantes en la selección de esa ápoca-, quienes se encuentran en el estadio abrazándose, vistiendo el uniforme de la selección de fútbol y una camisa blanca, uniéndose posteriormente dos personas más.

En lo que corresponde a la figura 6, su mensaje lingüístico señala: "Pase lo que pase nuestros Héroes saben que no están en "el lugar equivocado"”. La imagen denotada es asociada por presentar a una persona en posición de correr o trotar. Viste pantaloneta, tenis y la camiseta deportiva de color amarillo con azul (referida a la selección de fútbol) elevada a los hombros como una capa $y$ en la parte baja se encuentra el ícono de una entidad bancaria privada, Banco Davivienda.
FIGURA 6

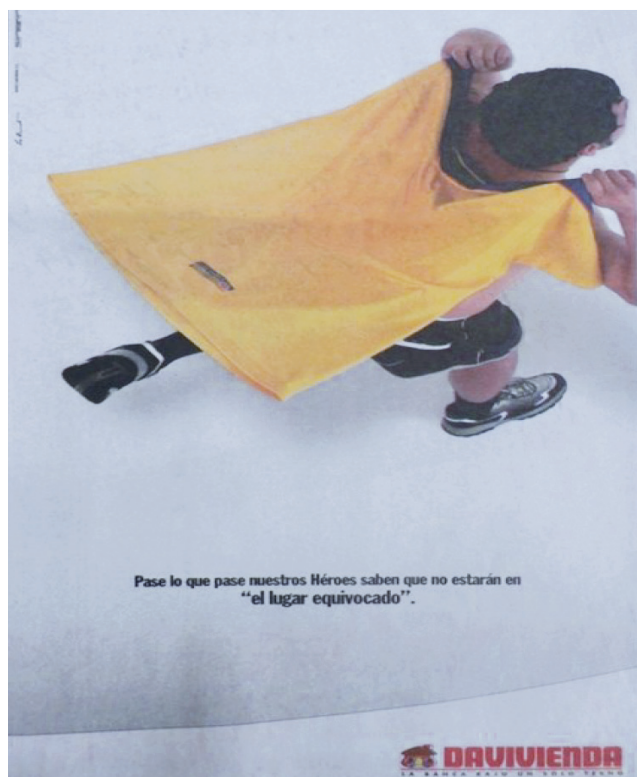

Fuente: El Espectador, 29 de julio de 2001, pág. 7c, sección: Copa América.

A partir de lo anterior, la imagen connotada de las tres imágenes (figuras 4,5 y 6 ) concibe al fútbol como un medio para la construcción de idea de nación. Se evidencia una transición de valores o sentimientos colectivos desde el plano bélico a uno regulado en la confrontación, cuyo objetivo es representado en la distinción máxima de campeón en el contexto 2001 como es la Copa América de la Paz.

En primer lugar, al retomar los postulados de Bathes (2008) acerca del deporte, este puede ser asociado con la construcción de sentimientos y referentes nacionales en el ámbito deportivo. En otras palabras, "el deporte permite ilustrar todos los valores morales: resistencia, sangre fría, temeridad, coraje. Los grandes jugadores no son estrellas son héroes" (p. 63).

Con lo señalado, el mensaje lingüístico y su imagen denotada permiten abordar la caracterización otorgada a los jugadores de la selección de fútbol para la época, como héroes construidos en el campo deportivo. Retomando los postulados de Dávila y Londoño (2002), 
la Selección Colombiana de Fútbol presenta un proceso de construcción de nación y de ídolos nacionales desde el año 1985. Siguiendo su perspectiva, en los años 80 se dio un proceso de consolidación del fútbol colombiano con dos facetas de manera análoga. Por un lado, la construcción de la imagen de lo colombiano, su interés en el fútbol y sus contradicciones. De otro lado, el rol que representó y significó Maturana para la Selección Nacional, donde su propuesta hacia:

mucho énfasis en que lo importante era jugar, divertirse, ser buenas personas, hombres íntegros, un grupo de amigos $y$, en la cancha, imponer las condiciones a partir de los rasgos técnicos y tácticos que mejor se adaptan al futbolista colombiano, a sus posibilidades y sus condiciones futbolísticas y personales (Dávila y Londoño, 2002, p. 94).

Asimismo, en el proceso de construcción y generación de discursos de nación e identidad nacional, el fútbol ayudaría a “...recomponer y relevar los desgastados papeles de las instituciones y las personas que habían jugado ese papel a lo largo de la historia de Colombia" (Dávila y Londoño, 2002, p. 95).

En el caso particular, dentro del contexto del 2001, la Selección Colombiana de Fútbol puede ser entendida en el presente texto como un referente de idea de nación en la medida que las imágenes construyen dicho concepto alrededor de un certamen deportivo. También, la construcción de referentes nacionales o héroes donde la camiseta y los colores nacionales son asociados con la paz.

Dentro de un ámbito social y nacional, estas imágenes se vinculan al fútbol como un referente de cohesión social. Esto último, se refiere a como el equipo nacional permitió vincular a la población bajo el enunciado de un sentimiento e idea común, la paz. La victoria deportiva es asociada con el proceso de paz en el año 2001, reflejado con la camiseta blanca utilizada por los jugadores en la final del certamen deportivo.

Cabe señalar, dentro de este contexto, la orientación y posicionamiento de la imagen publicitaria. Otorgando a la selección un referente de identidad nacional y de símbolos como son: el jugador, el aficionado y la nación. Siguiendo lo expuesto por Oliven y Damo (2006), la Copa América de 2001 se asocia con una realidad simbólica relacionada con el Estadonación y el fútbol, a partir de diversas características: "metafórica", entendida por estar más próxima a las representaciones; "analógica", la cual puede ser observada de forma empírica cuando los hinchas se perciben como pertenecientes a una comunidad de sentimiento denominada como nación; $y$ "complementaria", “... donde estado-nación y el fútbol establecen relaciones manteniendo cada una su autonomía" (Oliven y Damo, 2006, p. 21).

En relación con la "Copa de la Paz", la construcción de representaciones sociales alrededor de la selección anfitriona del evento, las imágenes se fundamentan en la socialización de una comunidad con sentimiento de lealtad $y$ el accionar del Estado dentro del contexto del proceso de paz, implicando así, como un certamen deportivo de fútbol “...pasa a ser una forma lúdica de sustituir a la guerra por un juego con vencedores y vencidos. Siendo así, hay un paralelismo entre acciones bélicas $y$ futbolísticas, estableciéndose una relación metafórica entre estados-nación y el fútbol" (Oliven y Damo, 2006, p. 21).

Además, las imágenes muestran a los jugadores como hinchas representando la búsqueda de una relación horizontal en el triunfo. Las imágenes y sus mensajes permiten relacionar un encuentro entre la comunidad política imaginada de Benedict Anderson. Cabe aclarar, que este autor entiende por nación "... una comunidad política imaginada como inherentemente limitada y soberana" (Anderson, 2011, p. 23).

Con lo anterior, las imágenes del triunfo deben ser leídas, interpretadas o comprendidas dentro de los límites o fronteras territoriales del país; asimismo, el plano bélico de la confrontación es manifestado en el ámbito deportivo y en el triunfo. El compañerismo es representado en el campo deportivo tanto en los jugadores como en los hinchas; es decir, dentro de la idea de nación, los mensajes señalados en las imágenes 
alentando el amor, la paz, el corazón y el sueño, significó otorgar e infundir sentimientos colectivos desde un mensaje de circulación nacional, involucrar a la población y motivar un segundo nombre como fue la "Copa de la Paz", dentro del contexto de diálogos en el año 2001.

Ahora bien, al articular lo mencionado con los planteamientos de Elias y Dunning (1995), la Selección Colombiana de Fútbol se asocia por su carácter civilizatorio en el autocontrol de la confrontación, la excitación o emoción del juego y la identificación como parte de un grupo expresado desde la imagen.

Como se mencionó, el fútbol implica la regulación en el juego con el fin de excluir la violencia o el daño al oponente. Los ejercicios corporales competitivos que han sido llamados como deporte, al estar regulados se han convertido o caracterizado en representaciones simbólicas, en las cuales sin confrontación militar ni violenta "...continúan siendo un ejercicio de competición que excluye hasta donde es posible las acciones violentas que puedan lastimar seriamente a los competidores" (Elias, 1995, p. 36).

Dentro de esta confrontación cabe destacar el autocontrol. En las actividades deportivas, esto implica no causar daño al oponente ni así mismo, respecto al uso de la violencia. A su vez, un deporte al implicar una lucha física no violenta, se caracteriza por generar un incremento “...en la tensión-emoción del placer anticipado, el esfuerzo humano para prolongar el placer puntual de la victoria en el remedo de batalla que es un deporte..." (Elias, 1995, p. 38). Implicando consigo, cambios en la estructura de la personalidad de las personas.

En el caso de las imágenes seleccionadas, la selección de fútbol inmersa dentro de una competencia deportiva, evidencia una regulación al interior del partido por autoridades institucionales (Confederación Suramericana de Fútbol) y la excitación o expresión de sentimientos $y$ de emociones dadas a conocer en la imagen desde los jugadores referentes del equipo de fútbol como en el hincha.

$\mathrm{El}$ autocontrol y carácter mimético alrededor del fútbol es inscrito en las imágenes, en el goce dentro de un escenario imaginario. En resumen, el triunfo de la Copa América de 2001 por parte de la selección colombiana de fútbol, al ser entendido por su carácter simbólico en el uso y control de la violencia, así como de las imágenes dentro del contexto de negociación, se constituyen en la expresión de un plano bélico que buscó ser reducido por medio del proceso de paz en consonancia al rol del Estado dentro del proceso civilizatorio.

Finalmente, dentro de la construcción de la idea de nación, las imágenes de esta sección son asociadas con el consumo y posicionamiento de una marca o producto nacional. Siguiendo la perspectiva de Luis Hernando Cuadrado (1992) sobre la función apelativa de la publicidad, esta se encuentra en "...todos los mensajes publicitarios, pero, desde una perspectiva visual, tiene una de sus más claras manifestaciones en los personajes que apelan al público. Con este procedimiento se intenta romper el carácter impersonal de la comunicación y hacerla más persuasiva" (p. 514). Un ejemplo de lo anterior se visualiza por medio de los iconos que acompañan las imágenes como son MasterCard, Reebok y Davivienda. Dentro del contexto de este certamen deportivo se identifica de manera paralela actores y productos enmarcados dentro la construcción de la idea de nación para el año 2001. Además, la compra o uso de productos son asociados a la nación como a una identidad nacional persuadiendo con la imagen denotada, connotada y el mensaje lingüístico medios de comunicación escrita de circulación nacional. Estos productos dentro del contexto de 2001 son reconocidos por medio del deporte $y$ articulados con la paz: "con la imagen se pretende canalizar el mensaje, sobre todo las connotaciones, hasta una lectura clara del contenido que se desea comunicar, eliminando cualquier resquicio de ambigüedad" (Hernando, 1992, p. 514).

\section{IMAGEN Y CONTEXTO NACIONAL}

En la figura 7 se despliega un mensaje lingüístico afirmando: "¡Hoy todos somos titulares!", "En la final de la Copa América nos la jugamos por la libertad de todos. No dejes que te metan en el otro equipo. Hoy en el estadio, o donde estés, muestra tu pasión por la liberación de quienes están secuestrados llevando contigo un elemento blanco: una camiseta, un brazalete, 
un sombrero, una bandera o un simple pedazo de tela. Exprésate mostrando en la ola o cuando saludes a tu equipo, para que seamos... Un solo equipo por la libertad de todos".

\section{FIGURA 7}

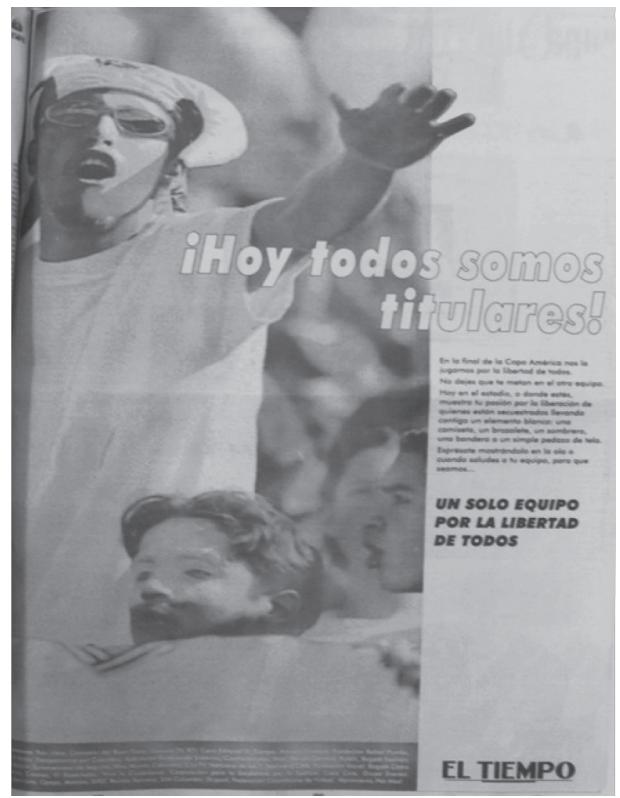

Fuente: El Tiempo, 29 de julio de 2001, pág. 13, sección: Copa América.

Igualmente, este mensaje lingüístico es acompañado de treinta y ocho entidades que lo convocan entre medios de comunicación, entidades públicas y privadas, así como marcas de consumo masivo en Colombia: País Libre, Convenio del Buen Trato, Caracol tv, RTI, Casa Editorial El Tiempo, Amway, Fenalco, Fundación Rafael Pombo, RCN Radio, Transparencia por Colombia, Asociación Rompiendo Silencios, Comfecámaras, Andi, Revista Cambio, Publik, Bogotá Fashion, Fundación Suramericana de Seguros, Miss Mundo Colombia, City tv, Noticiero de las 7, Noticiero cm\&, Fundación Social, Bogotá Cómo Vamos, Cromos, El Espectador, Viva la Ciudadanía, Corporación para la Excelencia por la Justicia, Coca Cola, Grupo Everest, Asobancaria, Opepa, Maloka, IDRD, Revista Semana, sim Colombia, Dupont, Federación Colombiana de Futbol y Movimiento ¡No Más!
A su vez, la imagen denotada se caracteriza por estar en blanco y negro. En el primer plano se encuentran un grupo de personas en el estadio donde se destacan dos en particular. Por un lado, un hombre vestido con un gorro deportivo y una camiseta blanca, que por su posición corporal y la mano izquierda es asociado con la realización de cantos. Por otro lado, se encuentra una persona con su rostro pintado sosteniendo en sus manos una camisa relacionada al deporte $y$ a la selección de fútbol.

En la figura 8 de esta sección, su mensaje lingüístico divulga: "Felicitaciones Colombia!", "Jugando en equipo, todos los colombianos podemos hacer más! Gracias Presidente Pastrana. Gracias muchachos. Gracias compatriotas por esta gran realización", "Conservatismo Colombiano. Partido Conservador Colombiano. Popular, moderno y de avanzada". La imagen denotada es descrita por tener como fondo un cielo junto con el icono del Partido Conservador y la bandera de Colombia ondeada, donde el azul ocupa mayor parte frente al amarillo y el rojo.

\section{FIGURA 8}

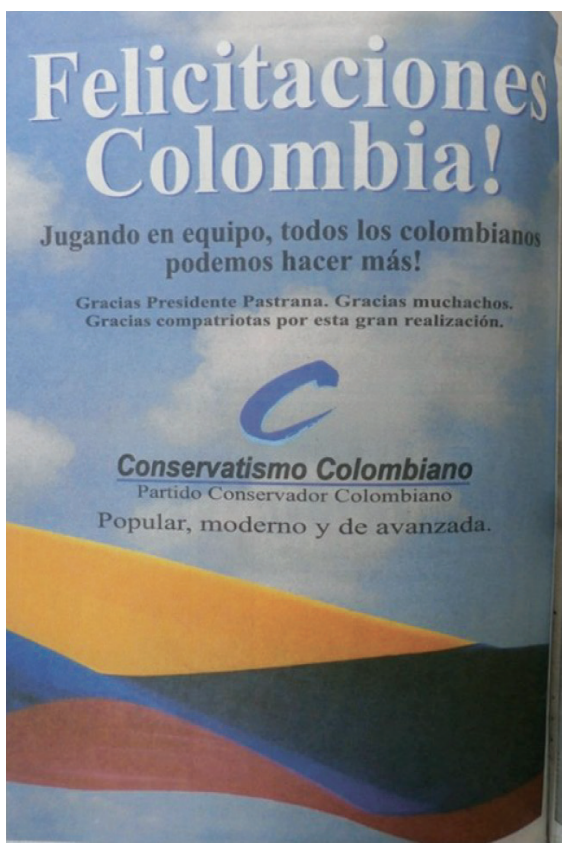

Fuente: El Tiempo, 29 de julio de 2001, pág. 3-16, sección: Deportes. 
A partir de lo anterior, la imagen connotada (figuras 7 y 8) es caracterizada por transmitir y posicionar un mensaje de paz desde el marco institucional. Buscó involucrar a las personas receptoras de la imagen de manera colectiva y de manera paralela entre el proceso de paz y la Copa América que acontecía para el año 2001. Implicó también, la definición del color blanco, el tricolor y la bandera nacional desde el partido político del gobierno central de la época (Conservador) y otras entidades. Con ello, evidencia la construcción imaginaria de una nación desde institucionales públicas como privadas y su legitimización social.

El mensaje y la imagen publicitaria pueden ser entendidas por infundir en la población receptora una acción y generar consigo un deseo o sentimiento común. En el caso particular, respaldar la paz desde la agenda de negociación con el deporte. Siguiendo la perspectiva de Barthes (1986), el "...texto constituye realmente el derecho a la mirada del creador (y, por tanto, de la sociedad) sobre la imagen: el anclaje es un control, detenta una responsabilidad sobre el uso del mensaje frente a la potencia proyectiva de las imágenes..." (p. 37).

Con lo anterior, las imágenes se caracterizan por el posicionamiento de un mensaje desde la perspectiva de su autor o creador proyectado en un medio de comunicación escrita. Esto hace referencia, en que la libertad fue conceptualizada (desde el partido político como por las treinta $y$ ocho entidades $u$ organizaciones) en un ámbito simbólico por medio del deporte. Se interpretó el éxito deportivo a uno social y político dentro del contexto de los diálogos de paz.

Asimismo, conforme a los acontecimientos previos al certamen deportivo como fue el secuestro de dirigentes deportivos y políticos, y la imagen connotada conceptualizada desde la mirada del creador, existió un interés en socializar una idea en común de nación vinculando a la población, los jugadores e instituciones estatales, frente al secuestro. Por otro lado, el significado de las imágenes sitúa la expresión de emociones y el autocontrol en el marco de la Copa América y el proceso de paz.
Al retomar los postulados de Dunning (1995) sobre la intervención de las nacionesEstados y las confrontaciones que se presentan entre los deportistas, se convierten estas últimas en "luchas reales" por el aumento de la presión social e importancia de los éxitos deportivos como un símbolo de estatus para la naciones. "Además, de esto, es el aumento del prestigio nacional que puede obtenerse triunfando en el deporte internacional lo que ha contribuido principalmente a que los gobiernos intervengan en las cuestiones deportivas..." (Dunning, 1995, p. 268).

En el caso particular de la "Copa de la Paz" y el carácter connotado del certamen deportivo sitúa la generación y excitación de emociones a partir del triunfo, donde es regulada la violencia dentro de la confrontación deportiva. Asimismo, las imágenes en el contexto de paz buscan la legitimidad del gobierno por medio del Partido Político Conservador para constituir un equipo y una nación enfocada en la libertad regulada y emplazada desde la institucionalidad.

Por otro lado, el partido político y las 38 organizaciones que se mencionan en el primer mensaje, permiten identificar una relación con las imágenes institucionales antes descritas en la primera parte (figuras 1, 2 y 3) a partir del uso de iconos nacionales como son el escudo y la bandera (figura 8). Al retomar la perspectiva de Barthes (1986):

si bien la connotación tiene significantes típicos de acuerdo con las sustancias utilizadas (imagen, palabra, objetos, conductas), tiene significados comunes: encontramos los mismos significados en la prensa escrita, la imagen o el gesto del actor (por eso la semiología solo es concebible en un marco que podríamos llamar total); este terreno común de los significados de connotación es el de la ideología que solo puede ser una y la misma, dadas una sociedad y una historia, sean cuales sean los significantes de connotación a que se recurra (p. 44-45).

A partir de lo señalado, las imágenes referentes al triunfo de la Copa de la Paz constituyeron consigo una imagen connotada asociada 
a una ideología dentro del contexto del 2001. En otras palabras, dentro del proceso de paz, la Copa América fue conceptualizada y expresada (significante) desde el ámbito institucional. Las imágenes dan a conocer una idea común sobre la libertad frente al secuestro y la conformación de una imagen de país o nación caracterizando a sus habitantes como compatriotas representados en la bandera nacional.

La ideología se caracteriza por transitar en el escenario público por medio de la imagen en medios de comunicación escrita. Esto hace referencia en que las instituciones estatales, un partido político $y$ diferentes organizaciones convocaron y conceptualizaron un mensaje en torno a la paz, indicando consigo la construcción de una idea de nación desde el ámbito político, económico y estatal.

Las imágenes implican una relación frente al accionar de la rama ejecutiva para el año 2001. En otras palabras, este certamen deportivo fue enfocado desde las intuiciones estatales por posicionar y socializar un acto simbólico mediante el uso del color blanco $y$ los colores de la bandera nacional. La confrontación deportiva al interior del campo de juego y la bélica del conflicto armado interno fueron articuladas bajo el lema de la paz y el cese de violencia mediante la solemnidad de un espectáculo deportivo como fue la Copa América.

\section{IMAGEN, IDEA DE NACIÓN Y SU POSICIONAMIENTO AL EXTERIOR}

Finalmente, la figura 9 en su mensaje lingüístico, especifica: "Vecinos y amigos como México, Uruguay, Honduras, Costa Rica, Chile, Perú, Brasil, Ecuador, Venezuela, Paraguay y Bolivia creyeron en nosotros (ese fue el más grande de los triunfos)". Asimismo, la imagen denotada es caracterizada por estar constituida por el mismo mensaje lingüístico. Al abarcar la totalidad de la página, por medio del nombramiento de los países participantes en la "Copa de la Paz" reafirma su significado desde los signos que conforman su escritura y en la parte final fue ubicado el icono de Supermercados de la Caja de Compensación Familiar (Cafam).

\section{FIGURA 9}

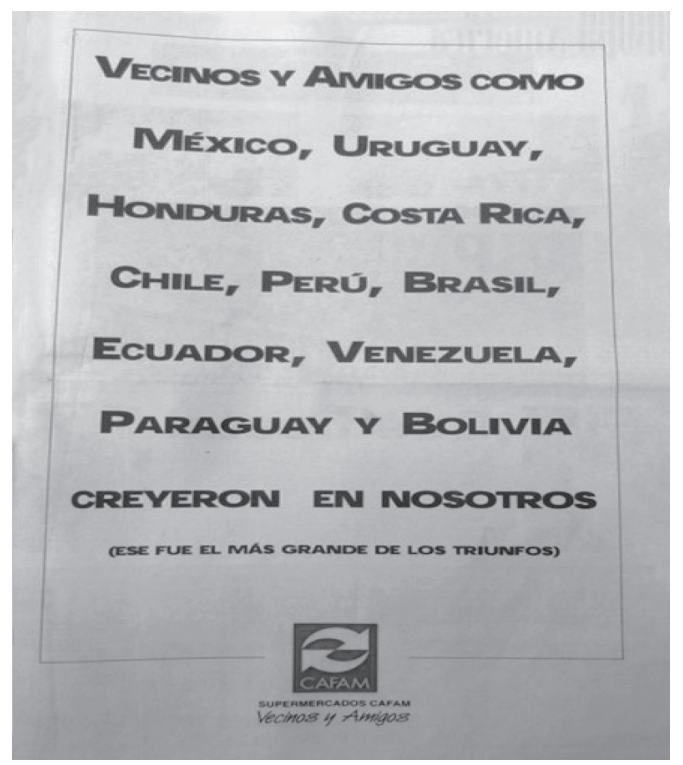

Fuente: El Tiempo, 30 de julio de 2001, pág. 11, sección: Copa América.

La figura 10 presenta en su mensaje lingüístico "Algunos nos llamaron violentos, otros ilusos y hoy después de hacer sentir a toda América como en casa, nos llaman Campeones" y "Telecom, solución de telecomunicaciones de la Copa América Colombia 2001". Esta imagen es articulada con la anterior, ya que su imagen denotada, no solo es constituida por ocupar la totalidad del espacio por medio del texto dentro de un primer plano sino por instituir una imagen de país entre el conflicto armado que acontecía para la época, el proceso de paz y el evento deportivo. Cabe señalar que en la parte inferior se encuentra los iconos de Empresa Nacional de Telecomunicaciones (Telecom). Una hormiga y un hemisferio global en relación a comunicaciones nacionales e internacionales por medio de los indicativos 09 y 009. 
FIGURA 10

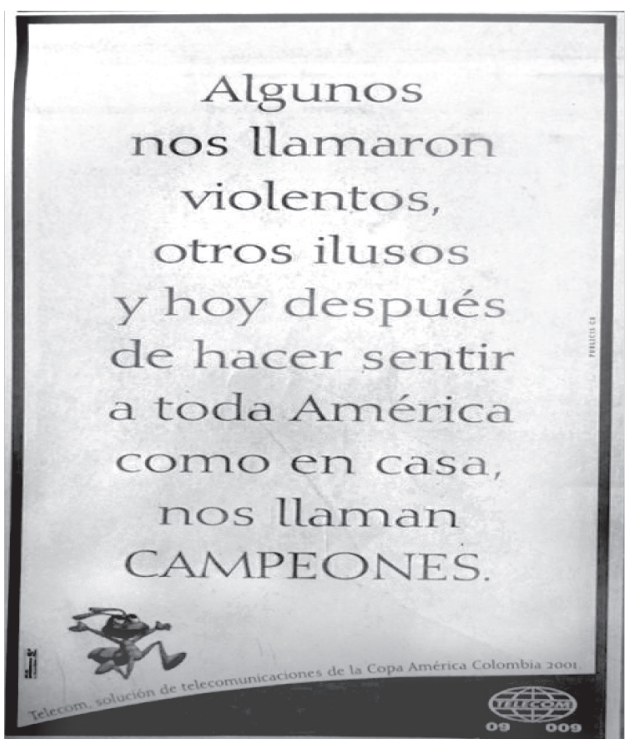

Fuente: El Tiempo, 30 de julio de 2001, pág. 16, sección: Copa América.

En la figura 11, su mensaje lingüístico afirma: "Una gran lección para el mundo", "Las barreras están en la mente", "Pensamos que podíamos hacerlo y lo hicimos", "Viva Colombia!!". La imagen denotada acompaña los textos con dos imágenes. Es decir, un jugador de fútbol en un escenario deportivo de fútbol donde el balón es ubicado en dirección frontal a la persona receptora de la imagen y el icono del Instituto Meyer en referencia a la enseñanza del inglés. Además, evidencia la construcción de un referente nacional como fue el fútbol para el año 2001 desde el idioma, los colores nacionales y la educación en lenguas extranjeras.

\section{FIGURA 11}

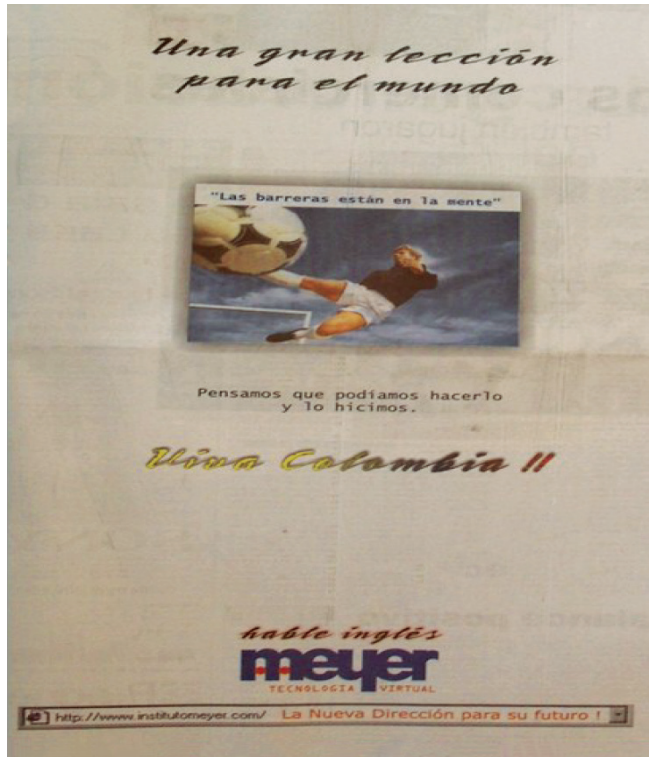

Fuente: El Tiempo, 30 de julio de 2001, pág. 23, sección: Copa América.

A partir de lo anterior, la imagen connotada (figuras 9, 10 y 11) es caracterizada por la construcción de nación para el contexto del 2001 dentro de un escenario nacional a uno internacional. En otras palabras, el triunfo de la Copa América se constituyó en una representación de país al interior del mismo como para el continente $y$ en particular con las selecciones deportivas que participaron en este certamen deportivo.

Retomando la perspectiva de Barthes (2008) frente al deporte $y$ la ciudad, esta última ha crecido pero "...ya no es ciudad, es un país, $y$ muchas veces es, por decirlo así, el mundo 
entero; el deporte es una gran institución moderna metida en el molde ancestral del espectáculo" (p. 71). En el caso particular de las tres imágenes de esta sección, su imagen connotada se orienta por dar un significado sobre país a través del fútbol dentro del contexto del proceso de paz. Implicó representar la nación por medio de las imágenes, donde el triunfo del certamen deportivo por parte de la Selección Colombiana de Fútbol, fue constituido por parte de los medios e instituciones en socializar un mensaje de paz frente a la violencia que acontecía para la época por el fútbol.

Por tanto, este evento deportivo permite ser entendido por generar un "pensamiento común" o propio frente al exterior. Esto hace referencia, retomando la perspectiva de Oliven y Damo (2002) en que los jugadores al estar inmersos dentro de una práctica deportiva, se convierten en embajadores de las naciones que representan. En el caso particular las selecciones y jugadores de fútbol que participaron en la Copa América de 2001, fueron referentes nacionales de un país, de nación y Estado frente a las doce selecciones participantes dentro del evento deportivo.

Al retomar los postulados de Elias y Dunning (1995), se evidencia al interior de un espectáculo deportivo como fue la Copa América del 2001 una "figuración". Conviene subrayar, que este concepto hace referencia a la interdependencia entre las personas en varios niveles 0 maneras $y$ en este deporte:

El proceso de juego es precisamente eso: una figuración móvil de seres humanos cuyas acciones $y$ experiencias se interconectan continuamente, un proceso social en miniatura. Uno de los aspectos que más nos enseñan del esquema rápidamente cambiante de un partido de fútbol es el hecho de que este esquema o modelo está formado por los jugadores de ambos bandos en sus continuos movimientos... Es necesario tener la capacidad de distanciarse del juego para reconocer que las acciones de cada lado se conectan constante $y$ recíprocamente con las de su contrario $y$, por tanto, que los dos equipos forman una sola figuración (pp. 70-71)

Frente a esto último, el fútbol representa una batalla mimética controlada y no violenta dentro de un escenario imaginario. Por lo tanto, Elias (1995) destaca una figuración conjunta entre dos equipos. Para el caso de 2001, por medio de los mensajes lingüísticos de las tres imágenes mencionadas, fueron reconocidas una serie de acciones e interacciones entre dos partes o más dentro del mismo certamen. La figuración es expresada en las imágenes, donde destacan una transición del carácter bélico a uno deportivo y constituir prestigio al exterior, siendo en este caso las selecciones de fútbol de América Latina. Asimismo, dentro de esta interpretación de la imagen connotada es importante destacar los tres aspectos de figuración emergente siguiendo los postulados de Dunning (1995). Estos son:

1) el hecho de que el deporte ha cobrado fuerza como una de las principales fuentes de emoción agradable; 2) el hecho de que se ha convertido en uno de los principales medios de identificación colectiva y 3) el hecho de que ha llegado a constituirse en una de las claves que dan sentido a las vidas de muchas personas (p. 266).

Con esto se hace referencia en asociar al fútbol con las imágenes en la generación o construcción agradable de emociones e identificación colectiva. Para el contexto de 2001, la "Copa de la Paz" tomó significado alrededor de una idea de nación y de país a partir del fútbol. Además, se concibe una definición de un "nosotros" frente a un "ellos" expresada en sus mensajes lingüísticos y socializado en el carácter connotado de la imagen a partir de la superación de obstáculos por medio de una ilusión compartida como es la paz y su reconocimiento interno como externo expresado en un icono nacional como fue el triunfo de la Copa América. Finalmente, la anterior aproximación interpretativa de las imágenes referentes al triunfo de la Copa América de 2001 y siguiendo la perspectiva de Barthes (2008): 
... hay en el hombre unas fuerzas, unos conflictos, unas alegrías y unas angustias; el deporte las expresa, las libera, las quema, sin dejar que nunca destruyan nada. En el deporte, el hombre vive el combate fatal de la vida, pero ese combate ésta distanciado por el espectáculo, reducido a sus formas, liberado de sus efectos, de sus peligros y sus vergüenzas: ha perdido su carácter nocivo, pero no su esplendor ni su sentido (p.73).

Por lo tanto, se enfatiza en el signo que constituye la imagen publicitaria para ese año: la asociación de una idea de nación, la restricción de la violencia al interior y exterior del escenario deportivo, vinculándolo con el significado otorgado a la "Copa de la Paz" desde el entorno institucional. Finalmente, fue establecida una relación entre las imágenes con el contexto en que se desarrolló el proceso de paz en Colombia para el 2001. Los mensajes lingüísticos evocaron sentimientos y una idea común de nación frente a una realidad expresada mediante imágenes publicitarias en medios de comunicación escrita.

\section{CONCLUSIONES}

En primer lugar, la imagen publicitaria referente al triunfo de la Copa América del 2001 fue significada y constituida en relación al proceso de paz y a la idea de nación. Con lo anterior, el certamen deportivo asignó un significado en torno a la paz frente al secuestro $y$ la violencia. Implicó también, la consecución de una definición de legalidad y control desde un referente institucional dirigido al espectador de la imagen.

Asimismo, con la publicación de imágenes publicitarias circuló una representación sobre la "Copa de la Paz" que transcendió de un referente deportivo a uno político. Las imágenes fueron usadas como elementos de socialización de una idea sobre nación y país dentro del contexto del proceso de paz. Con la incidencia de instituciones estatales, un partido político, entidades $\mathrm{u}$ organizaciones públicas y privadas, marcas de productos, entre otros.
En segundo lugar, la imagen publicitaria en referencia al deporte y la idea de nación se caracterizó por la regulación y excitación en la confrontación como también, a un plano bélico al interior y exterior del campo deportivo. El certamen deportivo dentro del proceso de paz que acontecía para la época, fue caracterizado desde el entorno institucional como elemento de reconocimiento e identificación en la población receptora de la imagen $y$ la generación de sentimientos o pasiones en referencia al fútbol entre jugadores, hinchas, instituciones u organizaciones.

Igualmente, el escenario de imitación bélico que caracterizó dicho deporte, para el año 2001 , estableció a través de la imagen posicionar una confrontación o dualidad entre la paz y conflicto. Involucrando consigo, un carácter connotado entre la legitimidad institucional como la realización del evento deportivo, conceptualizando un carácter simbólico o estatus nacional de país y nación para su proyección internacional.

En este aspecto, es relevante retomar los postulados de Elias y Dunning (1995) en la medida que el autocontrol, la interdependencia dentro de un proceso de civilización está presente en el deporte en su práctica y espectáculo. En el caso de la Copa América de 2001, persistió un ámbito regulatorio que ha estado presente en la profesionalización desde el escenario estatal y directivo. Además, la temática de la paz constituyó referentes nacionales desde el fútbol junto con los medios de comunicación escrita.

En tercer lugar, dando respuesta a la hipótesis planteada, la imagen connotada de la Copa América de 2001 estableció una ideología en referencia a la paz y la institucionalidad expresada en la imagen denotada sobre el fútbol. Asimismo, las imágenes se constituyeron dentro del contexto del proceso de paz en orientar la creencia (legitimidad) del accionar estatal como en la vinculación de la comunidad política.

Esto último, hace referencia en la definición de un pathos expresado en la imagen publicitaria en consonancia a la paz y el establecimiento de una ilusión o fraternidad que ha de ser infundida en las personas. Igualmente, 
el carácter denotado y connotado de la imagen publicitaria en referencia al triunfo del certamen deportivo fue asociado a una representación de nación dentro de una definición solemne del evento al interior de las fronteras imaginarias y su demostración externa frente a otras naciones.

Por otro lado, al retomar el carácter metodológico y los estudios latinoamericanos es relevante la perspectiva de Villena (2003) puesto que el presente texto se interesa por la problematización del deporte y la sociedad:

Es de esa forma que el espectáculo futbolístico ofrece un escenario en el que se construye, representa $y$ resignifica la propia identidad, a la vez que se adquirieren y reelaboran las imágenes que los "otros" tienen sobre "nosotros" y ellos mismos, interiorizando en ese proceso conceptos sobre lo que es ser un buen o un mal ciudadano, sobre cómo ser un buen o un mal hombre, sobre lo que es bonito y elegante o feo, etc. (p. 29).

En resumen, la interpretación de este evento deportivo junto con la imagen, permite profundizar continuidades y rupturas en la compresión social del fútbol dentro de la sociedad en medio de la negociación y conflicto que acontecía para la época en Colombia. Asimismo, la vinculación como la producción de datos empíricos, permite reconocer la circulación de mensajes de manera denotada y connotada en función de una identidad, nación, país e imaginarios desde la emisión y recepción de mensajes lingüísticos como de significados.

Finalmente, un posible escenario de interpretación entre el deporte y la idea de nación a partir de lo trazado en el presente texto es por medio de las diferentes delegaciones deportivas nacionales que participan en certámenes internacionales a nivel conjunto e individual. Por ejemplo: Juegos Olímpicos, Tour de Francia, Juegos Panamericanos, Torneos continentales, $y$ de las Confederaciones que hacen parte de la Federación Internacional de Fútbol Asociación (FIFA); con el objetivo de establecer una relación entre la representación de lo nacional y sus formas de expresión desde las imágenes difundidas dentro de un plano industrial y cultural.

Además, al cruzar las fronteras territoriales, imaginarias o regionales permite al deporte profundizar la conceptualización de certámenes deportivos realizados en el territorio nacional que convoquen participantes nacionales e internacionales. Esto en referencia a su participación en encuentros competitivos, donde el carácter imaginario de la nación está en discusión o definición y las formas de representación de un país en torno al deportista dentro de su contexto de producción.

\section{REFERENCIAS}

Alabarces, P. (2006). Fútbol y Patria: el fútbol y la (invención de) las narrativas en la Argentina del Siglo xx. Papeles del CEIC, 1, (25), 1-18.

Anderson, B. (2011). Comunidades Imaginadas. Reflexiones sobre el origen y la difusión del nacionalismo. México: Fondo de Cultura Económica México D.F. Colección popular.

Barthes, R. (1986). Retorica de la imagen. En Barthes, R. Lo obvio y lo obtuso. Imágenes, gestos, voces (pp.29-47). Barcelona, España: Ediciones Paidos.

Barthes, R. (1994). La mitología hoy. En Barthes, R. El susurro del lenguaje. Más allá de la palabra y la escritura (pp.8387). Barcelona, España: Ediciones Paidos Ibérica, S.A.

Barthes, R. (2008). Del deporte y los hombres. Barcelona, España: Ediciones Paidos Ibérica, S.A.

Barthes, R. (2009). Elementos de semiología. En Bathes, R. La aventura semiológica (pp.23-111) Barcelona, España: Ediciones Paidos Ibérica, S.A.

Congreso de Colombia (05 de enero, 2009). Ley nro. 1270. Por la cual se crea la Comisión Nacional para la Seguridad, Comodidad y Convivencia en el Fútbol y se dictan otras disposiciones. Recuperado de http://www.alcaldiabogota.gov.co/sisjur/ normas/Norma1.jsp?i=34491

Dávila, A y Londoño, C. (2002). La nación bajo un uniforme: La selección colombia 
1985-2001 (II). En Bolívar, I., Ferro, G. y Ladrón de Guevara, A. (Eds.) Cuadernos de Nación Belleza, futbol y religiosidad popular (pp.85-118). Bogotá, Colombia: Imprenta Nacional de Colombia, Ministerio de Cultura.

Elias, N. y Dunning, E. (1995). Deporte y Ocio en el proceso de la civilización. México D.F., México: Fondo de Cultura Económica.

Gómez, G. (mayo-agosto, 2014). Goles son amores... un acercamiento al Programa Goles en Paz. De la seguridad a la integralidad (un vacío). En Análisis Político, 27 (81), 80-97.

Hernando, L. (1992). Análisis semiótico del mensaje publicitario. En Fernández, A., Gómez, C. y Paz, J. (Eds.), Semiótica y modernidad: actas del $V$ Congreso Internacional de la Asociación Española de Semiótica, La Coruña, 3-5 de diciembre de 1992. Vol. 2., 1994. 513-523.

Jaramillo, C. (2007). 2001 La Copa América El golazo de la paz. En Jaramillo, C. Fútbol en Colombia,(pp.780-796). Bogotá, Colombia: Villegas Editores.

López, J. (2015). Padre Alirio López. Fútbol en Paz. El Enganche. Recuperado de http:// www.elenganche.es/reportaje/padrealirio-goles-por-la-paz/

Medina, C. (2009). FARC-EP, Pastrana y el proceso de paz en el Caguán. En Medina, C.; Oliven, R. y Damo, A. (2006). Fútbol y cultura. Enciclopedia Latinoamericana de Sociocultura y Comunicación. Colombia: Grupo Editorial Norma.

Villena, S. (2003). El fútbol y las identidades. Prologo a los estudios latinoamericanos. En Alabarces, P. (Comp.) Futbologías. Fútbol, Identidad y Violencia en América Latina,(pp.21-35). Buenos Aires, Argentina: Consejo Latinoamericano de Ciencias Sociales (clacso).

Villena, S. (julio-agosto, 2009). Fútbol, Discurso publicitario e Imaginarios nacionalistas en Costa Rica. En: Razón y Palabra, 14 (69), 1-21.

Weber, M. (1997). Economía y Sociedad. Esbozo de sociología comprensiva. Bogotá, Colombia: Fondo de Cultura Económica.

Fecha de ingreso: 13/01/2017 Fecha de aprobación: 22/06/2017 
